\title{
ANALISIS KESULITAN BELAJAR SISWA PADA MATA PELAJARAN MATEMATIKA
}

\author{
Andani Salamah Syakur ${ }^{\left.{ }^{*}\right)}$, Ratih Purnamasari ${ }^{\text {a) }}$, Dadang Kurnia ${ }^{\text {a) }}$ \\ a) Universitas Pakuan, Kota.Bogor, Indonesia \\ *) e-mail korespondensi: andanisalamah36@gmail.com
}

\section{Riwayat Artikel}

diterima 25 November 2021 direvisi 14 Desember 2021 disetujui 30 Desember 2021

\begin{abstract}
Abstrak.
Penelitian ini dilakukan dengan tujuan untuk menganalisis kesulitan belajar siswa pada mata pelajaran matematika. Bertempat di Sekolah Dasar Negeri Neglasari Kota Bogor dilaksanakan pada semester genap Tahun Ajaran 2020/2021. Dalam penelitian ini penulis menggunakan penelitian kualitatif dengan metode deskriptif. Prosedur pengumpulan data dilakukan secara triangulasi yaitu gabungan dari hasil observasi (pengamatan), wawancara dan dokumentasi. Data dianalisis dengan mereduksi data yang tidak relevan, memaparkan data secara sistematis, dan menarik kesimpulan terhadap temuan penelitian. Hasil penelitian menunjukkan bahwa kesulitan belajar yang dialami siswa pada mata pelajaran matematika yaitu kesulitan dalam memahami konsep, kesulitan dalam memahami bahasa matematika, kesulitan dalam perhitungan dan kesulitan memecahkan masalah. Hal ini dapat disimpulkan bahwa siswa masih mengalami kesulitan belajar pada mata pelajaran matematika. Solusinya siswa harus mendapatkan penanganan yang tepat, dengan usaha guru yang didukung juga oleh orangtuanya, serta semangat dan motivasi siswa untuk meningkatkan kemampuan berhitungnya.
\end{abstract}

Kata Kunci: Kesulitan Belajar, Matematika

\begin{abstract}
ANALYSIS OF STUDENT LEARNING DIFFICULTIES IN MATHEMATICS
Abstract. This research was conducted with the aim of analyzing students' learning difficulties in mathematics. Located at the Neglasari State Elementary School, Bogor City, it was held in the even semester of the 2020/2021 Academic Year. In this research, the writer uses qualitative research with descriptive method. The data collection procedure was carried out by triangulation, namely a combination of the results of observations (observations), interviews and documentation. Data were analyzed by reducing irrelevant data, presenting data systematically, and drawing conclusions from research findings. The results showed that the learning difficulties experienced by students in mathematics subjects were difficulties in understanding concepts, difficulties in understanding mathematical language, difficulties in calculations and difficulties in solving problems. It can be concluded that students still have difficulty learning in mathematics. The solution is that students must get the right treatment, with the efforts of teachers who are also supported by their parents, as well as the enthusiasm and motivation of students to improve their numeracy skills.
\end{abstract}

Keywords: Difficulty learning, Mathematics.

\section{PENDAHULUAN}

Dalam proses pembelajaran disekolah, suatu kegiatan belajar mengajar tidak selamanya dapat berjalan dengan lancar, kemungkinan terdapat suatu masalah yang banyak terjadi, umumnya pada masalah kesulitan belajar yang sering dialami siswa. Kesulitan belajar merupakan suatu permasalahan dan hambatan dalam proses belajar yang dialami siswa, sehingga siswa sulit untuk melakukan kegiatan belajar secara optimal.

Kesulitan belajar juga merupakan keadaan masalah yang dialami seseorang dalam melakukan suatu perubahan pengetahuan, pemahaman, sikap dan tingkah laku, kebiasaan dan perubahan aspek lainnya yang ada pada anak setelah berinteraksi dengan lingkungannya. Kesulitan belajar dapat pula disebabkan oleh faktor biologis, psikologis dan sosiologis, semua hal tersebut dapat mengakibatka hasil belajar maupun prestasi belajar anak berada dibawah rata-rata.

Kesulitan belajar yang sering dialami siswa adalah kesulitan belajar dalam berhitung. Operasi hitung penjumlahan, pengurangan, perkalian dan pembagian merupakan operasi hitung dasar yang harus dikuasai oleh siswa. Faktanya masih banyak siswa yang memiliki nilai kecil pada materi ini yang diduga karena memiliki kesulitan dan kelambanan dalam menguasai dasar berhitung dan menyelesaikan soal pada materi tersebut.

Bila ditinjau dari penelitian terdahulu tentang kesulitan belajar, yaitu penelitian yang dilaksanakan oleh Utari, Wardana dan Damayani (2019) Jurnal Ilmiah Sekolah Dasar dengan judul "Analisis Kesulitan Belajar Matematika dalam menyelesaikan Soal Cerita". Hasil penelitian menunjukkan bahwa sisa kelas IV yang berjumlah 10 siswa dari 15 siswa mengalami kesulitan belajar matematika dalam menyelesaikan soal cerita. Kesulitan belajar matematika menyelesaikan soal cerita yang terjadi di kelas IV SD meliputi kesulitan memahami konsep, kesulitan dalam keterampilan dan kesulitan memecahkan masalah. Faktor yang meyebabkan kesulitan belajar matematika berasal dari faktor internal dan faktor eksternal. Faktor internal yang berasal dari siswa meliputi IQ atau intelegensi, sikap siswa dalam belajar matematika, motivasi belajar siswa yang masih rendah, 
kesehatan tubuh yang tidak optimal dan kemampuan penginderaan yang kurang. Sedangkan faktor eksternal yang berasal dari luar siswa antara lain kurangnya variasi mengajar guru, penggunaaan media pembelajaran yang belum maksimal, sarana prasarana di sekolah serta lingkungan keluarga.

Peneliti telah melakukan observasi yang dilaksanakan di salah satu sekolah di Kota Bogor yaitu SDN Neglasari yang berada di Komplek Asrama Brimob Ks. Tubun Jalan Lhokseumawe Kelurahan Cibuluh Kecamatan Bogor Utara Kota Bogor. Penelitian ini bertujuan untuk mengetahui kesulitan belajar siswa pada mata pelajaran matematika materi operasi hitung campuran pada siswa kelas V di Sekolah Dasar Negeri Neglasari Kecamatan Bogor Utara Kota Bogor Semeseter Genap Tahun Ajaran 2020/2021. Observasi dimasa pandemi ini dilakukan secara tatap muka langsung menyambangi 5 siswa tersebut dikediamannya masing-masing.

Subjek yang diteliti yaitu 5 orang siswa yang berinisial VMY, MRH, ZM, RNR dan HF. Peneliti melihat bahwa masih banyak siswa yang mengalami kelambanan dalam berhitung juga mengalami kesulitan dalam berhitung dan mengerjakan soal operasi hitung campuran. Siswa yang memiliki hambatan dan kesulitan dalam berhitung harus mendapatkan penanganan yang tepat, dengan usaha guru yang didukung juga oleh orangtuanya, serta semangat dan motivasi siswa untuk meningkatkan kemampuan berhitungnya.

Kesulitan belajar merupakan kondisi siswa mengalami hambatan atau gangguan dalam belajar. Parnawi (2019:99) berpendapat bahwa kesulitan belajar adalah suatu kondisi dimana anak didik tidak dapat belajar secara wajar disebabkan adanya ancaman, hambatan atau gangguan dalam belajar. Definisi serupa diungkapkan oleh Idrus (2018:201) Kesulitan belajar adalah hambatan yang dialami sehingga tidak tercapainya tujuan belajar secara sempurna, serta pembelajaran tidak berjalan sesuai dengan rencana.

Selanjutnya menurut Sumarsono, dkk (2020:96) kesulitan belajar merupakan suatu keadaan dimana siswa tidak dapat belajar sebagaimana mestinya yang disebabkan oleh hambatan atau gangguan tertentu dalam proses pembelajaran sehingga siswa tidak dapat mencapai hasil belajar yang diharapkan. Adapun pendapat yang dikemukakan oleh Hariyanto dan Mustafa (2020:27) Kesulitan belajar merupakan suatu kondisi dimana anak didik tidak dapat belajar dengan baik disebabkan karena adanya gangguan, baik berasal dari faktor internal siswa dibatasi faktor itelegensi maupun faktor eksternal siswa. Masroza (2013:215-216) mengemukakan bahwa kesulitan belajar ini merupakan gangguan yang secara nyata ada pada anak yang terkait dengan tugas umum maupun khusus, yang diduga disebabkan karena faktor disfungsi neurologis, proses psikologis maupun sebab-sebab lainnya sehingga anak yang berkesulitan belajar dalam suatu kelas menunjukkan prestasi belajar rendah.

Berbeda dengan pendapat Marlina (2019:46) Kesulitan belajar merupakan suatu kondisi terjadinya penyimpangan antara kemampuan yang sebenarnya dimiliki dengan prestasi yang ditunjukkan yang termanifestasi pada tiga bidang akademik dasar seperti membaca, menulis, dan berhitung. Menurut pendapat Yeni (2015:1) Kesulitan belajar juga dapat diartikan sebagai ketidakmampuan anak dalam menyelesaikan tugas-tugas yang diberikan oleh guru. Anakanak dengan ketidakmampuan belajar memiliki karakteristik unik mereka sendiri dan gaya belajar yang berbeda. Kesulitan belajar yang sering terjadi yaitu kesulitan belajar pada mata pelajaran matematika.

Matematika merupakan ilmu dasar dari segala bidang ilmu pengetahuan yang sangat penting untuk kita ketahui. Oleh sebab itu, dimulai dari usia pendidikan dini yang biasa disebut dengan PAUD, Sekolah Dasar, sampai Perguruan Tinggi selalu melibatkan pembelajaran matematika pada mata pelajaran atau mata kuliah yang bersifat wajib. Hal tersebut sejalan dengan pendapat yang dikemukakan oleh Widyasari dkk (2015:2) Matematika merupakan salah satu bidang studi yang ada pada semua jenjang pendidikan, mulai dari tingkat sekolah dasar hingga perguruan tinggi. Hal tersebut senada dengan pendapat yang dikemukan oleh Anggraeni dkk (2020:26) Matematika merupakan salah satu bidang studi yang dipelajari mulai dari tingkat sekolah dasar hingga perguruan tinggi.

Menurut Fahrurrozi dan Hamdi (2017:3) Matematika adalah suatu disiplin ilmu yang sistematis yang menelaah pola hubungan, pola berpikir, seni, dan bahasa yang semuanya dikaji dengan logika serta bersifat dedukatif, matematika berguna untuk membantu manusia dalam memahami dan menguasai permasalahan sosial, ekonomi dan alam. Sama halnya seperti yang dikemukakan oleh Yayuk (2019:3) Matematika merupakan ilmu universal yang mendasari perkembangan teknologi modern, mempunyai peran penting dalam berbagai disiplin dan memajukan daya pikir manusia.

Adapun menurut pendapat Yayuk, dkk (2018:2) Matematika adalah suatu bidang ilmu yang berisi tentang konsep dan prinsip matematika dimana penyajiannya menggunakan simbol (lambang) untuk melatih penalaran supaya berpikir kritis, logis, analitis dan sistematis dalam menyelesaikan masalah. Sejalan dengan yang dikemukakan oleh Susanto (2016:185) Matematika merupakan salah satu disiplin ilmu yang dapat meningkatkan kemampuan berpikir dan berargumentasi, memberikan kontribusi dalam penyelesaian masalah sehari-hari dan dalam dunia kerja, serta memberikan dukungan dalam pengembangan ilmu pengetahuan dan teknologi. Hal tersebut didukung oleh pendapat Syahputri (2018:90) Matematika merupakan salah satu mata pelajaran yang memberikan kontribusi positif dalam tercapainya masyarakat yang cerdas, bermartabat melalui sikap kritis dan berfikir logis.

Berdasarkan kajian teoritik diatas, dapat disintesiskan bahwa kesulitan belajar merupakan suatu kondisi seseorang yang menyebabkan orang tersebut tidak dapat belajar dengan baik dan menunjukkan hasil belajar dibawah rata-rata dikarenakan adanya faktor internal dan eksternal yang menyebabkan siswa mengalami hambatan maupun kelambanan yang terjadi pada saat proses pembelajaran. Sedangkan matematika merupakan suatu ilmu dasar dari semua ilmu pengetahuan yang ada pada semua jenjang pendidikan untuk meningkatkan kemampuan berpikir 
matematis seseorang agar dapat menguasai konsep-konsep matematika serta mampu berpikir kritis dan logis dalam menyelesaikan masalah yang ada di dalam kehidupan seharihari. Kesulitan belajar matematika pada materi operasi hitung dapat disebabkan karena siswa lamban dalam berhitung, siswa tidak memahami dan mengingat materi serta kebingungan, juga mengalami kesulitan verbal dalam menyelesaikan soal serta siswa malas mengerjakan latihan soal untuk mendalami materi.

\section{METODE PENELITIAN}

Penelitian yang dilaksanakan peneliti menggunakan jenis pendekatan kualitatif deskriptif. Penelitian dilaksanakan di Sekolah Dasar Negeri Neglasari Bogor di Komplek Asrama Brimob Ks. Tubun Jalan Lhokseumawe Kelurahan Cibuluh Kecamatan Bogor Utara Kota Bogor, Jawa Barat. Subjek penelitian adalah 5 orang siswa kelas VA kesulitan belajar matematika, orangtua siswa dan guru kelas VA di Sekolah Dasar Negeri Neglasari Bogor Semester Genap Tahun Pelajaran 2020/2021.

Penelitian kualitatif adalah penelitian yang bertujuan untuk mengungkapkan data yang diperoleh dari lapangan dengan cara menguraikan sesuatu seperti apa yang ada dilapangan. Dengan pendekatan kualitatif ini peneliti akan menggambarkan atau menganalisis setiap individu atau sekelompok kecil dalam kehidupan dan pemikirannya. Penelitian kualitatif ini melibatkan maupun menggali informasi yang ada melalui 5 orang siswa, 5 orangtua siswa dan guru kelas VA.

Siklus prosedur pengumpulan data terdiri dari studi pendahuluan, tahapan perencanaan. Fokus penelitian, pengumpulan data dengan menggunakan metode triangulasi, analisis data, pengumpulan data, pengecekan keabsahan data dan penarikan kesimpulan. Teknik pengumpulan data pada penelitian kualitatif dapat dilakukan dengan cara melakukan observasi(pengamatan), interview(wawancara), dokumentasi dan gabungan ketiganya (triangulasi).

Analisis data yang digunakan adalah model Miles and Huberman yang dikutip oleh Sugiyono (2019:323) mengemukakan bahwa analisis data yang dilakukan dalam penelitian kualitatif yaitu melalui proses reduksi data, penyajian data, dan kesimpulan (verifikasi). Menurut pendapat Sudaryono (2019:554) mengemukakan bahwa uji keabsahan data dalam penelitian kualitatif adalah (1) Uji kredibilitas data, (2) Uji transferabilitas, (3) Uji dependabilitas, dan (4) Uji konfirmabilitas.

\section{HASIL DAN PEMBAHASAN}

Setelah melakukan penelitian, peneliti berhasil mengumpulkan data yang berkaitan dengan fokus penelitian. Pada saat observasi, kelima siswa tersebut masih sering keliru dan kurang teliti dalam berhitung, serta kurang memahami soal cerita dengan baik. Peneliti melakukan penelitian ini dimulai pada tanggal 31 Mei 2021 sampai 15 Juni 2021. Hasil dari penelitian ini menemukan banyak temuan pada siswa khususnya kesulitan yang dialami siswa pada mata pelajaran matematika materi operasi hitung dari tahapan yang dilakukan seperti hasil observasi, hasil wawancara dan hasil dokumentasi yang dilakukan oleh peneliti kepada subjek. Data yang diperoleh ini berasal dari hasil observasi ketika melaksanakan kegiatan wawancara dan dokumentasi datadata siswa wawancara yang telah dilakukan diantaranya kepada siswa yang sebagai subjek, guru kelas, serta orang tua siswa. Penelitian ini dilakukan secara terus menerus sampai tuntas sehingga data yang diperoleh mencapai titik jenuh.

Adapun hasil temuan yang telah didapatkan oleh peneliti yang merupakan hasil wawancara dengan semua subjek, orang tua dan guru atau wali kelas dapat diketahui bahwa kesulitan belajar yang di alami siswa yaitu siswa mengalami kesulitan dalam mengingat dan memahami materi, siswa merasa ragu dan kebingungan dalam menjawab soal, siswa jarang menggunakan langkah-langkah atau cara dalam menyelesaikan soal perhitungan, siswa kurang bisa memahami soal cerita dan mengerjakan atau menjawabnya, siswa mengalami kesulitan dalam berhitung terutama pada perkalian dan pembagian.

Tes tertulis adalah serentenan pertanyaan maupun pelatihan serta alat yang digunakan untuk mengukur pengetahuan, intelegensi, kemampuan dan bakat yang dimiliki individu maupun kelompok. Peneliti melakukan tes tertulis yang berupa soal-soal untuk mengetahui apa kesulitan yang dialami siswa dalam belajar matematika khususnya materi operasi hitung di kelas V SDN Neglasari.

Berdasarkan hasil analisa yang telah peneliti lakukan terhadap siswa yang memiliki kesulitan belajar pada mata pelajaran matematika di kelas V A SDN Neglasari. Kesulitan yang dialami siswa ketika kegiatan pembelajaran yaitu: kesulitan dalam memahami konsep matematika, kesulitan dalam berhitung, kesulitan dalam memahami bahasa matematika (maksud soal dan maksud penjelasan) dan kesulitan dalam memecahkan masalah.

Kemampuan dan kesulitan siswa pastinya berbedabeda, siswa yang memiliki kemampuan tinggi tidak akan mengalami kesulitan dalam setiap kegiatan belajarnya, sedangkan siswa yang memiliki kemampuan rendah tentunya akan mengalami kesulitan dalam kegiatan belajarnya. Peneliti memberikan test tertulis berupa soal untuk mengetahui kesulitan apa yang dialami dan dihadapi siswa dalam pembelajaran matematika. Setelah peneliti memberikan tes berupa soal kepada siswa, selanjutnya peneliti mengkaji jawaban para siswa, dan dari hasil jawabannya peneliti dapat mengetahui kesulitan-kesulitan apa saja yang dialami siswa dalam menyelesaikan soal-soal pada materi operasi hitung.

Kesimpulan dari hasil jawaban siswa yang mengalami kesulitan ditemukan beberapa siswa sudah dapat menentukan mana yang diketahui dan mana yang ditanyakan. Sebagian siswa kurang memahami maksud soal antara soal penjumlahan, pengurangan, perkalian dan pembagian yang berbentuk soal cerita, rata-rata siswa tidak mengerti cara menghitung pembagian dengan benar, siswa juga kurang teliti atau ceroboh dalam menghitung dan mengerjakan soal yang diberikan dan melakukan kesalahan dalam menjawab soal tes yang diberikan oleh peneliti, kurangnya kemampuan pemecahan masalah yang dimiliki oleh siswa, sehingga hasil dari jawaban yang siswa kerjakan salah dan tidak sesuai dengan hasil yang diinginkan. 
Berdasarkan hasil observasi dan wawancara tersebut dapat disimpulkan bahwa kesulitan belajar siswa pada mata pelajaran matematika itu disebabkan karena siswa tidak memahami konsep matematika mengenai materi yang mereka pelajari, siswa tidak mengerti tentang konsep pembagian dan siswa kurang hafal perkalian dan pembagian. Selanjutnya siswa sering melakukan kekeliruan atau kesalahan dalam berhitung dan kelambanan dalam berpikir maupun mengerjakan soal, kurangnya kemampuan pemecahan masalah yang dimiliki oleh siswa serta kurangnya pemahaman tentang bahasa matematika sehingga siswa mengalami kesulitan dalam belajar matematika.

Hasil wawancara, observasi dan penelusuran dolumen mengenai kesulitan belajar siswa pada mata pelajaran matematika ini menunjukkan fakta-fakta empirik sebagai berikut :

\section{A. Kesulitan memahami konsep matematika}

Memahami konsep matematika sangat perlu dipahami oleh siswa agar nantinya dapat diterapkan dalam memecahkan masalah pada saat belajar matematika maupun dalam kehidupan sehari-hari. Berdasarkan hasil observasi dan wawancara dapat diketahui bahwa siswa masih kesulitan dalam memahami konsep dasar dari materi operasi hitung dan soal latihan yang diberikan berbentuk cerita, khususnya pada konsep dasar perkalian dan pembagian. Siswa juga mengalami kesulitan dalam mengingat materi dan kurang dapat menguasai materi, contohnya seperti pada saat diberi penjelasan oleh guru maupun oleh peneliti siswa hanya ingat di hari itu saja, kemudian di esok harinya pada saat mengerjakan soal yang sama, siswa tidak bisa mengerjakan soal tersebut karena siswa sudah lupa mengenai cara-cara pengerjaannya. Maka dari itu, guru harus terus memberi latihan soal dan terus menjelaskan cara pengerjaannya secara berulang-ulang.

\section{B. Kesulitan dalam berhitung}

Kesulitan atau kesalahan dalam berhitung ini biasanya disebabkan karena siswa megalami kesulitan dalam memahami maksud soal serta siswa belum menguasai konsep dasar matematika. Hasil penelitian menunjukkan bahwa siswa mengalami kesulitan dalam perhitungan. Contoh kesalahan yang dilakukan oleh siswa yaitu siswa mengerjakan soal dan cara yang digunakan dengan benar pada soal penjumlahan, pengurangan dan perkalian, akan tetapi jawaban akhir siswa kurang tepat. Hal tersebut disebabkan karena siswa belum menguasai konsep dasar dan melakukan kesalahan dalam perhitungan, siswa kurang teliti pada saat mengerjakan soal, serta siswa tidak bisa mengerjakan soal operasi hitung campuran yang terdapat soal perkalian dan pembagian.

Adapun contoh kesalahan atau kekeliruan yang dilakukan siswa pada soal perkalian seperti 0 × 8 jawabannya " 8 " yang seharusnya jawaban yang benar adalah " 0 " karena semua angka yang dikalikan "0" tentunya jawaban yang benar yaitu "0". Siswa menghitung perkalian 1-10 menggunakan penjumlahan berulang. Semua siswa mengalami kesulitan dalam menghitung pembagian dikarenakan semua siswa belum hafal perkalian.

\section{Kesulitan membedakan simbol}

Anak yang mengalami kesulitan belajar sering memperlihatkan kesulitan dalam memahami dan mengenal simbol-simbol matematika. Berdasarkan hasil penelitian menunjukkan bahwa siswa tidak mengalami kesulitan dalam mengenal dan membedakan simbol. Hal tersebut terbukti ketika soal yang diberikan peneliti pada nomor 1 merupakan soal penjumlahan, sehingga siswa menuliskan jawabannya menggunakan simbol "+".

\section{Kesulitan menentukan nilai tempat}

Dalam pelajaran matematika, nilai tempat bilangan perlu dipahami oleh siswa terutama menuliskan lambang atau angka yang lebih besar dari 10. Berdasarkan hasil penelitian yang telah dilakukan oleh peneliti, dapat diketahui bahwa semua siswa dapat menentukan nilai tempat dengan baik. Pada saat peneliti mencoba memberikan contoh soal dengan cara mendikte, semua siswa dapat menuliskannya dengan baik.

\section{E. Kesulitan memecahkan masalah}

Pemecahan masalah merupakan inti dari pembelajaran matematika. Tujuan dari pembelajaran matematika yakni agar siswa mampu memecahkan permasalahan yang terdapat pada soal matematika maupun dikehidupan sehari-hari. Penerapan keterampilan maupun pengetahuan mengenai pemecahan masalah sangat bermanfaat bagi kehidupan sehari-hari. Berdasarkan hasil penelitian yang peneliti lakukan dapat ditemukan bahwa siswa masih mengalami kesulitan dalam memecahkan permasalahan pada soal matematika dikarenakan siswa tidak memahami prosedur penyelesaian serta kurang memahami maksud soal. Terdapat beberapa siswa yang merasa ragu-ragu dan mengalami kelambanan dalam mengerjakan soal matematika, serta membutuhkan waktu yang lama pada saat mengerjakan soal terutama soal perkalian dan pembagian yang bentuk cerita.

\section{F. $\quad$ Kesulitan dalam memahami bahasa matematika}

Pemahaman bahasa matematika yang kurang yakni dimana dalam pemahaman bahasa matematika siswa belum begitu memahami, terkadang masih salah dalam proses pengerjaannya. Kesulitan dalam memahami bahasa matematika juga disebabkan oleh sulitnya siswa dalam memahami istilah-istilah dalam materi matematika. Berdasarkan hasil penelitian diketahui bahwa siswa mengalami kesulitan dalam memahami bahasa matematika. Kesulitan yang dialami siswa diantaranya dalam menggunakan operasi hitung yang dipakai dalam menjawab soal, hal tersebut dikarenakan siswa masih belum memahami maksud dari soal tersebut. Contoh kesalahan yang sering di alami siswa yaitu pada mengerjakan soal cerita, siswa sering keliru dalam menentukan apakah itu soal pertambahan, pengurangan, perkalian atau pembagian. Seperti soal cerita perkalian, siswa menjawabnya dengan cara pertambahan.

Berdasarkan hasil temuan penelitian yang dilakukan ketika peneliti mengobservasi siswa yang mengalami kesulitan belajar pada mata pelajaran matematika, terlihat siswa mengalami kesulitan maupun hambatan yang terjadi pada saat siswa sedang melakukan kegiatan belajarnya 
sehingga hasil yang didapatkan siswa dalam menyelesaikan soal terdapat kesalahan dan tidak sesuai dengan apa yang diinginkan. Fakta tersebut sesuai dengan teori yang diungkapkan oleh Sumarsono, dkk (2020:96) kesulitan belajar merupakan suatu keadaan dimana siswa tidak dapat belajar sebagaimana mestinya yang disebabkan oleh hambatan atau gangguan tertentu dalam proses pembelajaran sehingga siswa tidak dapat mencapai hasil belajar yang diharapkan.

Anak yang berkesulitan belajar biasanya menunjukkan kelemahannya dalam berhitung. Fakta ini sesuai dengan teori yang dikemukakan oleh Marlina (2019:46) Kesulitan belajar merupakan suatu kondisi terjadinya penyimpangan antara kemampuan yang sebenarnya dimiliki dengan prestasi yang ditunjukkan yang termanifestasi pada tiga bidang akademik dasar seperti membaca, menulis, dan berhitung. Prinsip belajar dalam matematika yaitu tentang prasyarat pembelajaran. Jika siswa belum memahami penjumlahan maka perkalian akan terhambat, kemudian jika siswa belum memahami pengurangan dan perkalian maka pembagian akan terhambat pula. Hampir dalam setiap materi matematika selalu menggunakan operasi hitung dalam pembelajarannya, hal tersebut berarti keterampilan operasi hitung menjadi bagian yang sangat penting dalam pelajaran matematika dan tentunya diperlukan agar siswa dapat belajar matematika dengan baik bagi siswa. Seseorang yang tidak dapat menghitung dengan benar, artinya dia tidak memiliki keterampilan operasi hitung.

Oleh karena itu, apabila tingkat penguasaan materi prasyarat siswa tinggi, maka materi tertentu akan lebih mudah di pahami. Sebaliknya, apabila tingkat penguasaan materi prasyarat siswa rendah, maka siswa akan kesulitan dalam memahami materi tertentu sehingga akan berdampak pada hasil yang kurang optimal serta akan menghambat proses pembelajaran. Siswa yang memiliki kemampuan rendah tentunya akan mengalami kesulitan dalam kegiatan belajarnya. Gambaran seperti ini yang biasanya sering terjadi dan sering dialami siswa ketika belajar matematika. Menurut pendapat Yeni (2015:1) Kesulitan belajar juga dapat diartikan sebagai ketidakmampuan anak dalam menyelesaikan tugas-tugas yang diberikan oleh guru.

Hal tersebut sesuai dengan peneliti sebelumnya oleh Suwarto (2018), Hasil analisis yang didapat: (1) Letak kesulitan siswa dalam memahami operasi bilangan adalah dalam hal fakta, hal ini ditunjukan ketika menyelesaikan soal bentuk cerita, dalam operasi penjumlahan soal cerita dalam katagori kurang baik yaitu sebesar 25\% siswa dapat mengerjakan soal dengan benar. Pada soal cerita operasi pengurangan kemapuan penyelesaian siswa dalan katagori kurang baik yaitu sebesar 22,5\% siswa yang dapat mengerjakan soal dengan benar. (2) Siswa masih mengalami kesulitan jika dimodelkan dalam bentuk abstrak, hal ini terlihat pada soal yang dimodelkan abstrak pada operasi pengurangan sebesar 50\% siswa dapat menyelesaikan soal dengan baik dan pada operasi pengrungan terdapat $37,5 \%$.

Penelitian lain yang mendukung ditulis oleh Emi Zakiyah dkk (2019), Hasil penelitian menyebutkan (1) bentuk kesulitan belajar matematika materi operasi hitung campuran yaitu siswa sulit menghitung saat mengerjakan latihan, memahami simbol; memahami konsep dan menuliskan hasil penjumlahan bilangan. (2) faktor yang menyebabkan kesulitan belajar matematika materi operasi hitung campuran yaitu faktor internal seperti konsentrasi belajar tidak bertahan lama, kemampuan mengingat beberapa siswa rendah, siswa berkesulitan dalam memahami maksud soal dan kesulitan menghitung. Faktor eksternalnya seperti guru dalam memberikan pemahaman terlalu cepat, tidak menggunakan media dan siswa yang sering berbicara pada saat guru menjelaskan. (3) upaya untuk mengatasi kesulitan belajar yaitu diadakannya bimbingan belajar, mengadakan remedial untuk yang nilainya rendah, mengubah metode yang digunakan, memberi motivasi dan nasehat, menggunakan media yang sesuai materi.

\section{KESIMPULAN}

Berdasarkan pembahasan dari penelitian dan temuan data yang telah diuraikan sebelumnya, maka peneliti dapat menyimpulkan bahwa siswa sudah dapat membedakan simbol-simbol dan dapat menempatkan nilai tempat dengan baik. Akan tetapi, siswa masih kesulitan dalam memahami konsep matematika, kesulitan dalam berhitung, kesulitan dalam memahami bahasa matematika serta kesulitan dalam memecahkan masalah yang terdapat pada soal. Penyebab dari siswa mengalami kesulitan belajar dikarenakan siswa memiliki kecerdasan dibawah rata-rata. Siswa yang memiliki hambatan dan kesulitan dalam berhitung harus mendapatkan penanganan yang tepat, dengan usaha guru yang didukung juga oleh orangtuanya, serta harus selalu diberi semangat dan motivasi siswa untuk meningkatkan kemampuan berhitungnya.

\section{REFERENSI}

Anggraeni, S. T., Muryaningsih, S., \& Ernawati, A. (2020). Analisis Faktor Penyebab Kesulitan Belajar Matematika di Sekolah Dasar. JRPD (Jurnal Riset Pendidikan Dasar), Vol.1 No.1, 25-37.

Fahrurrozi dan Hamdi. 2017. "Metode Pembelajaran Matematika". Lombok Timur: Universitas Hamzanwadi Press.

Hariyanto dan Mustafa. 2020. "Pengajaran Remedial dalam Pendidikan Jasmani”. Banjarmasin: Lambung Mangkurat University Press.

Idrus, Enjang. 2018. "Membongkar Psikologi Belajar Aplikatif". Bogor: Guepedia Publisher.

Marlina. 2019. “Asesmen Kesulitan Belajar”. Jakarta: Prenadamedia Group.

Masroza, Fitria. 2013. "Prevalensi Anak Berkesulitan Belajar Di Sekolah Dasar Se Kecamatan Pauh Padang”. Jurnal Ilmiah Pendidikan Khusus. Volume 1 No. 1.

Parnawi, Afi. 2019. "Psikologi Belajar". Yogyakarta: CV. Budi Utama.

Sudaryono. 2019. Metodologi Penelitian Kuantitatif Kualitatif dan Mix Method. Depok: Rajawali Pers.

Sugiyono. 2019. Metode Penelitian Kuantitatif Kualitatif dan R\&D. Bandung: Alfabeta. 
Sumarsono, Puji dkk. 2020. "Belajar dan Pembelajaran di Era Milenial". Malang: Universitas Muhammadiyah Malang.

Susanto, Ahmad. 2016. Teori Belajar dan Pembelajaran di Sekolah Dasar. Jakarta: Prenada Media Group.

Suwarto. 2018. "Analisis Kesulitan Belajar Operasi Hitung pada Siswa Kelas Satu Sekolah Dasar". Jurnal Pendidikan Matematika 7(2), 285-294.

Syahputri, Nita. 2018. Rancang Bangun Media Pembelajaran Matematika Sekolah Dasar Kelas 1 Menggunakan Metode Demonstrasi. Jurnal Sistem Informasi Kaputama (JSIK), Vol.2 No.1, 89-95.

Utari, Wardana dan Damayani. 2019. “Analisis Kesulitan Belajar Matematika dalam Menyelesaikan Soal Cerita”. Jurnal Ilmiah Sekolah Dasar 3 (4), 534-540.

Widyasari, Meter dan Negara. 2015. “Analisis KesulitanKesulitan Belajar Matematika Siswa Kelas IV Dalam Implementasi Kurikulum 2013 di SD Piloting SeKabupaten Gianyar". Jurnal PGSD Universitas Pendidikan Ganesha. Vol.3 No.1, 1-11

Yayuk, dkk. 2018. "Pembelajaran Matematika yang Menyenangkan”. Malang: Universitas Muhammadiyah Malang.

Yayuk, Erna. 2019. "Pembelajaran Matematika Sekolah Dasar”. Malang: Universitas Muhammadiyah Malang.

Yeni, Ety Mukhlesi. 2015. "Kesulitan Belajar Matematika di Sekolah Dasar" .Jurnal Pendidikan Dasar (JUPENDAS). Vol 2 No. 2. 1-10.

Zakiyah,Emi dkk. 2019. Analisis Kesulitan Belajar Matematika Materi Operasi Hitung Campuran Siswa Kelas IV di MI Hijriyah II Palembang. Jurnal Ilmiah Pendidikan Guru Madrasah Ibtidaiyah 9(1), 41-50. 